\title{
Comparing City Policies on Mandatory Drug Testing: A Process Evaluation
}

Presidential decree and federal legislation have resulted in substantial employoe drug testing at all levels of government as well as among private sector contractors. Joining the Wor on Drugs, many other employers have taken up the practice voluntarily. However we may foel about the arguments for and against drug testing - whether on the basis of public safety, integrity, access to sensitive information, etc. - the fact remains that drug testing policies are non-uniform and unevenly applied, and the common testing fochnologies are urreliable. If we believe as a society that arug testing serves a legitimate public function consistent with our cultural and legal values, then uniform standard's and procedures must be developed. If not, we should give greater consideration to altemative measures, such as employee education and assistance.

\section{by RUTH ANN STRICKLAND and MARCIA LYNN WHICKER}

Ince President Reagan issued an Executtve Order in September 1986 calling for a drug-free workplace, much debate and controversy has emerged over mandatory drug testing in the workplace. The President's order took aim at federal employees who held "sensittve" or "public safety" positions. ${ }^{1}$ The signal given by this executtve order, In addition to the War on Drugs mentality and the recognized problems associated with drug abuse in the United States, has catapulted drug testing onto the public agenda.

Major legislation has further formalized the importance of drug testing and its increasingly accepted use in the public sector. The federal Ant1Drug Abuse Act of 1988 (P.L. 100-690) has contributed to the spread of drug testing in the public sector. Title $V$, Subtitle $D$ of this act requires reciplents of federal grants and contracts to implement drug-free workplace policles. The following conditions are supposed to be met:

1. Contractors and grantees should publish and distribute to workers a policy forbidding the use of ulegal drugs in the workplace.

2. They should estabilsh drug-free workplace programs which inform employees about the dangers of drugs and the penalties that will be imposed if drugs are used at work.

3. Employees must notify the contractor or grantee within five days if 
they are convicted of a drug-related workplace offense and the employee is also obligated to inform the government of this infraction within ten days.

4. Employees who abuse drugs should face disciplinary measures and/or be required to successfully participate in a drug rehabilitation program.

5. The government has three options for punishing contractors and grantees who do not meet the above requirements:

(a) temporarily suspend payments to contractors or grantees;

(b) terminate contracts or grant agreements; and

(c) bar contractors or grantees from federal work for a period of up

to five years.

Contractors and grantees may also be punished if a significant number of employees are convicted of drug-related workplace crimes and it is clear that employers have not made a "good falth effort" to implement drug-free workplace provslons. ${ }^{2}$ These provisions particularly apply to businesses with contracts valued at more than $\$ 25,000$ and all federal grant recipients. Thousands of businesses and millions of employees are threatened by the withdrawal of federal funds if drug-free workplace standards are not met. ${ }^{3}$

\section{Potential Advantages of Mandatory Drug Testing}

To the extent that mandatory drug testing might deter drug usage, not only in the workplace but among the young who might be tempted to experiment with drugs, it could be useful. From studies on drug abuse in the workplace. it is well known that drug usage lowers productlvity and performance levels. ${ }^{4}$ Alcohol and drug abuse reaches into every industry in the United States. Substance abusers are late for work three times more frequently than the average employee. 5 In comparison to the average worker, substance abusers are sixteen times more likely to miss work days. They are four times more likely to be involved in on-the-job accidents and five times more likely to fle compensation claims. ${ }^{\circ}$ it is estimated that one out of every seven workers in the United States is affected at the workplace by drug or alcohol addiction.?

As a result, substance abuse is very costly in terms of productivity and on-the-job injurles. In 1986, for example, the United States Chamber of Commerce estimated that drug and alcohol abuse cost employers approximately \$60-100 billion a year in lost productivity. It is further estimated (based on 1983 statistics) that annually there are ten million injuries from alcohol alone-two million may be disabling and there may be as many as 18.000 fatalities."

The rationale for mandatory drug testing revolves around three central, but controversial, tenets:

1. Drug testing enables the employer to maintain the integrity of the employee's job performance.
2. Drug testing will preserve the public safety as well as each employee's safety.

3. Drug testing allows employers to identify drug users and channel them into employee assistance Programs for the purpose of rehabilitation. ${ }^{8}$

Job performance in "sensittve-public safety" positions is particularly important. Substance abusers may be more apt to have accidents as in the case of the Conrall engineer in the January 1987 Amtrak collision near Baltimore, Maryland. Not only performance, but employee integrity. may be affected by drug abuse. Drugs alter decision-making abilities and it has been shown that workers who abuse drugs are more prone to theft. ${ }^{10}$ Integrity in public service is invaluable particularly in law enforcement where officers in drug units must not be tainted by illegal drug usage. Confidentiality is often stressed in public service and may be impaired by drug abuse. People who are entrusted with the public safety and welfare may be poor guardians unless drug abuse is detected and treated." Drug testing does not have to be punlttve and can be used positively by allowing organizations to identify substance abusers, channel them into rehabilitation programs and then allow them to return to the workplace drug-free.

\section{Widening the Net of Social Control}

The integrity of the employee in the area of job performance is a particular concern in the public sphere where employees have access to sensitive information and where employees are involved in drug interdiction. However, many other professionals might be prime targets for drug tests; including judges, correctional employees, cash register operators, accountants, teachers and so on. The list may go on indefinitely as more rationalizations are developed for widening the net of social control through mandatory drug testing.

Drug testing for public safety could add other occupational groups to the rolls of those who should be tested; including police offlcers, nuclear plant employees, doctors, nurses, ambulance personnel, dispatchers, auto mechanics, airline pllots, alr traffic controllers, firefighters, and all transportation workers. The dimension of employee safety further opens the door for more testees, including any employees who depend on their reflexes and the abilities of other employees (i.e., factory workers using heavy equipment or construction workers). If drug tests are to be used to identify substance abusers and subsequently to reform them and make them producttve and reliable, the net of soclal control is cast wider to test more groups of people. ${ }^{12}$

\section{The Disadvantages of Mandatory Drug Testing}

Drug testing is one component of a substance abuse program. As a screening mechanism, it may have some useful purposes. But it also has some significant limitations. Three broad questions underscore these 
limitations: 1) Are drug testing packages accurate? 2) Are the monetary costs of testing prohibltive? and 3) Does drug testing violate due process and indtvidual rights?

There are five types of drug-screening methods used in industrial and public sector drug testing. These include the Enzyme Multiplied Immunoasay Test (EMIT). Radio-Immunoasay (RIA). Thin Layer Chromatography (TLC), Gas Chromatography (GC) and Mass Spectrometry (MS). Each type of test has inherent validity problems, strengths and weaknesses..$^{13}$ EMT, RIA and TLC yield inaccurate results even when properly administered. They may yield false posittves by identifying a clean urine sample as tainted with illegal drugs. One study reported a 66.5 percent rate of false posittves among 160 urine samples from participants in a methadone treatment program. ${ }^{14}$ The National Institute on Drug Abuse (NIDA) reported that error rates in drug tests are actually greater than the rate of ulegal substance abuse in the general working population. ${ }^{15}$

The unattracttveness of relying solely on these tests is intensifed by the fact that EMrT might mistake ordinary, over-the-counter drugs such as Contac, Sudafed or Nyquil for illegal substances. This phenomenon is called "cross reacttvity." Certain diet pllls, decongestants and heart medications may register as amphetamines, whereas cough syrups (containing dextromethorphan) and prescription antiblotics may imitate cocalne. Datril, Advil and Nuprin sometimes mimic marijuana. Even some common everyday foods may be mistaken for lllegal drugs. Poppy seeds may register as heroin and morphine: herbal teas may be confused with cocalne. It is estimated that EMIT, for example. generally issues false pasitives five to 25 percent of the time. Yet companies that market EMIT tests often claim high rates of accuracy and reliabllity. ${ }^{16}$

EMIT and RIA do not work well when urine samples are more acidic or more akaline than normal; $\mathrm{pH}$ concentrations warp enzyme reactions. Stale urine or urine not maintained at optimal temperature may also lead to bad test results. The chief attraction of these initial tests is low costs which are estimated at $\$ 15$ to $\$ 25$ per test. Still, follow-up tests are essental with elther EMT, TLC or RIA ${ }^{17}$

Initial urine testing has critical fallings. The drugs under heavy scrutiny (i.e. cocaine and alcohol) are least susceptible to detection. Cocaine use is hard to detect since its chemical traces disappear in a few days. Alcohol, which is legal but considered detrimental to job performance, dissipates within twelve to 24 hours. On the other hand. urine testing is very sensitive to marijuana. Urine screens do not check for the presence of tetrahydrocannabinol (THC)-the intoxicant. Instead. THC's by-product metabolite which appears after THC breaks down and is no longer intoxicating is targeted. Thus, tests determine marjuana use but not actual intoxdcation on the Job. This metabolite may be active and detectable for weeks after use of THC and the test may even pick up on passtve inhalation. Other drugs may have a similar characteristic- permitting detection of by-products long after the initial period of intoxication. ${ }^{18}$

Since an employer's drug test often can not demonstrate the recency of use or distinguish between chronic use and experimental use. It is severely limited. If such tests can not measure present intoxdcation or fix the time perlod when drugs were used, they can not accurately determine jo impairment as a result of substance abuse. In addition, the chain-ofjob imparment as a resul of subste that the sample is correctly matched custody procedures usod the person who provided it add another layer of problems. For a with the person who provided it add another layer of problems. For a proper chain-of-custody, a person must be watched carefully while providing the sample; storage locations of the samples must be secure; signatures of persons handling samples must be obtained; and secure shipment to a laboratory generally is required. Ensuring the integrity of the chain of custody imposes more labor and shipping costs. If proper monitoring is not performed, drug users may alter their urine samples by moniture salt or they may substitute adding neutrailzing substances such as table salt or that Mountain Dew, a "clean" urine sample. ${ }^{\circ}$ It has recently been argued that Mountaln Dew. a soft drink, has the same qualities as a urine sample in pH composition and could be a possible substitute if properly warmed for the occasion.

Confirmatory tests include gas chromatography trometry (MS). These tests are more expensive, must be performed in trometrites and are very accurate. The GC/MS identifies substances from urine samples by breaking them into smaller molecular fragments from urine samples by breaking them ectrons. The purpose of this test is by bombarding the specimen wint that will demonstrate the presence of to produce a molecular fingerprint that will demonstrate the presence be a particular compound. Positive EMIT, RIA or TLC results should be subjected to GC/MS results since its accuracy level approaches 99.98 percent. To obtain this high level of accuracy, organizations will pay percent. To obtain this high level of ac/MS system costs $\$ 100,000$ to dearly. Laboraloquire; techniclans earn about $\$ 50$ per hour. If these $\$ 150,000$ are contracted out, the costs range from $\$ 30$ to $\$ 100$ per sample services are contractaboratory and the volume of work submitted by the depending on the

The statistical unreliabllity of drug tests also represents a fundamental flaw. The likelihood that a test represents a true positive indicator of drug flaw. The likelihood that a toff value used when determining the degree to usage depends on the cutofi value used whigs. For example, if an organization assumes that five percent of a group of employees engages in illegal zation assumes that ire peration proceeds with a drug screening program that uses a 95 percent accuracy level to screen the group, the program will that uses a 95 percent accuracy level to screen the group, the progran wil issue one false positive for every three true posittive results. If it is assumed that only two percent of the group uses If President Reagan's Executtve every four results will be false positives. ferral workers, an estimated Order were enforced on all 2.8 million federal workers, an estlen and would 
be unjustly fired or disciplined.21 Of course, just an initial test for all of these federal workers would cost, at $\$ 10$ per test, approximately $\$ 28$ million. If only flve percent (or 140,000 employees) were to recelve confirmatory tests at $\$ 50$ per test, the costs would run an additional $\$ 7$ million.

Besides the potential financial burdens represented by mass drug screening. there are greater costs that can not be measured. The qualitative costs of drug screening include an invasion of privacy, a helghtened sense of distrust between labor and management, a bowering of worker morale, and a distinct presumption of gullt as employees must prove their innocence. The legal question in the courts vis-a-vis mandatory drug testing in the public sector is whether the intrustveness of drug testing is mittigated by the governmental interests of safety in the workplace, employee integrity, and a reduction in the general demand for illegal drugs by requiring drug-free workplaces. The Fourth Amendment issues associated with drug testing (i.e. search and seizure and the right to privacy) are not a challenge to the governmental goals but are more directly questioning whether these goals can best be obtained by mandatory drug testing.20

\section{The Courts, Drug-Testing and Privacy}

Generally, the lower federal courts have supported a reasonable susplcion standard before an employee can be tested for drugs. The employer must make a decision to test based on objecttve facts and observations that drug use is occurring..$^{23}$ Balancing prtvacy against job performance, the New York Court of Appeals held that mandatory dru testing by urinalysis of probationary school teachers was illegal and an unjustifled invasion of prtvacy. ${ }^{2 x}$

By relying on a reasonable suspicion standard, the courts have generally volded the use of random drug testing. Drug screening programs that test employees randomly where there is not an identified drug problem, no sensitive position and no threat to public safety are more likely to be held as contrary to the Fourth Amendment. ${ }^{25}$ However the Department of Transportation's random drug testing plan was upheld without prejudice in the U.S. District Court due to the sensittvity of transportation jobs and the need to protect public safety as well as the plaintiffs unpersuastve argument that the testing imposed unreasonable burdens on them. ${ }^{26}$

Recent Supreme Court rulings have generally upheld mandatory drug testing where safety-sensitivity needs appeared to require it. Specifically, employees involved in transportation, drug interdiction or phocilly, firearms may reasonably be tested under the Fourth Amendment. At the same time, the Court also ruled that those applicants applying for positions requiring them to handle "classified" materials did not necessarlly fall into the same category as the above-mentioned positions and their prtvacy interests should be given greater consideration. ${ }^{27}$

\section{Process Dvaluation}

The implementation of drug-free workplace programs in the public sector is underway. In order to evaluate these programs, we surveyed 1,000 city managers nationwide in cities with populations of 10,000 residents or above. The list of city managers was obtained from the International City Management Association (ICMA). There are 2,758 known city managers in cities with populations of 10,000 or above. The ICMA list of managers represents a survey of their organlzation's membership and may not include all city managers. Nationally there are 7.095 members; 4.906 of them are employed as city managers, according to ICMA's survey. Surveys were representattvely sent to all 50 states; we recetved responses from a total of $\mathbf{4 8}$ states.

The 1,000 surveyed city managers were selected by sending surveys to every third manager on the ICMA list, which was arranged according to zip code and therefore also arranged according to region. Each surveyed city manager recelved a 20-question survey, consisting primarlly of openended questions about their drug screening policles. (See Figure 1 for a copy of the survey.)

Through the survey instrument, we compare and contrast city personnel policies for the purpose of developing a composite description of: 1) drug-screening programs nationally and 2) differences that might be attributed to city size. The two most important criteria for analyzing these programs are: 1) due process and individual rights and 2) the punitive versus rehabilitative nature of the drug programs. Two additional criterla included to evaluate the varlations among these policles are: 1) how drug screening affects labor-management relations and 2) the direct costs associated with drug screening.

Varlous questions contalned in the survey were particularly almed at assessing whether the programs protected due process and individual rights by showing concern for privacy and by demonstrating an awareness of the problems in obtaining accurate drug test results. Questions directly related to due process and individual rights were questions 6, 7, $8,9,10,11,12,13,16,17$, and 18 . These questions sought to gauge the impact of drug testing on due process issues along six dimensions: 1) Which employees are targeted for drug screening and why?: 2) Are drug screenings mandatory and if so, are they conducted regularly or infrequently?; 3) Are they randomly administered and/or based on a probable cause finding? Are they announced or unannounced?; 4) Is the policy itself well-publicized?; 5) What type of initial test is employed? Are there follow-up screenings for those who test posittvely? and 6) Are there concerns over the accuracy of the tests as administered in the various jurisdictions?

Other questions were almed at determining whether the drug- screen- 


\section{Figure 1 \\ Drug Screening Policy Survey}

The following is a series of questions designed to obtain an understanding of how city managers across the nation are addressing the use of drug testing for city employes in their various jurisdictions. This survey is being distributed to 1,000 randomly selected city managers for the purpose of research. Names of city managers will remain confidential in any reporting of the data derived from this survey. The name of the city will also be withheld upon the request of the respondent. Your response to these questions and your return of this survey in the enclosed, stamped envelope would be greatly appreciated. Thank you very much for your participation.

If you have any questions concerning this survey, foel free to contact Dr. Ruth Ann Strickland at Appalachian State University. She may be reached at (704) 262-6169 or 262-3085. Fe日l freo to leave messages at $3085 \mathrm{H}$ she is not avallable at her office number (6169). For results of the survey, you may mail a stamped, self-addressed envelope to: Dr. Ruth Ann Strickland, Department of Political Science and Criminal Justice, Appalachian State University, Boone, North Carolina 28608.

1. Your name

2. City State

3. Approximate Size of City (Please drde one of the following to Indicate the approximate population size of your jurisdiction).
(A) $10,000-24,999$
(E) 250,000-449,999
(B) $25,000-49,999$
(C) $50,000-99,999$
(D) $100,000-249,999$
(F) $500,000-1,000,000$
(G) Over $1,000,000$

4. Do you have a drug screening policy for selected city employees? If not, why not? Are you considering the Implementation of such a policy? Why?

Please comment:

5. If you have a drug screening policy, consider the following possible objectives and rank those that apply to your jurisdiction in order of importance from 1 (the top objective) to 5 (the objective of least concern).

[] To maintain the performance levels of the employees

[] To ensure the honesty and integrity of employees in sensitive jobs

] To maintain employeo safety

To identify dug users for rehabilitation purposes

To protect the safety of the public

Other (please specify):

6. Which city employees (i.e., police or firefighters) are targeted for drug screening?

7. Why were these specific groups targeted?
Tigure 1, continued

. How regularly are drug screenings conducted? once a week? once a month? other?

9. Are drug screenings mandatory for the targeted groups? If so, why? H not, whynot?

10. Are drug screenings random (administered to everyone or to randomly selected hdividuals) for the targeted groups? If so, why? If not, why not?

11. Does your jurisdiction base drug screenings on a probable cause finding? Why? Why not?

12. Are tests announced or unannounced? Why was one approach selected over another?

13. Are there follow-up screenings for those who test positive for drug usage? Why or why not?

14. What are the consequences of testing positive? Please circle one or more of the following responses as they apply to your jurisdiction.

(A) Those who test positive are subject to disciplinary measures

(A) Those who test positive are encouraged to attend counseling and/or to participate in an employee assistance program

(C) Those who test positive are immediately discharged

(D) Other (please spectfy):

\section{Comments:}

15. What are the estimated costs of dug screening in your jurisciction (i.e., the cost of the test itself and the administering of the tests)?

16. Is the crug screening policy itself (whether tests are announced, whether they are random, and the action taken on a positive test result, etc.) well-publicized to every employee in your municipality?

17. What type of dug screening test is employed? blood tests? urine samples? other?

18. Do you feel the drug tests employed in your jurisdiction are accurate? Whyor why not?

19. Have any legal challenges been mounted against the drug screening policy adopted in your jurisdiction? if 80 , on what grounds?

20. Have there been any successful legal challenges of the drug screening policy in your jurisdiction? Have there been alterations of the chug screening policy due to possible challenges? 
Ing programs used nationwide are basically punittve or rehabilitative in orientation. Question 5 partially reveals how the goal of identifying drug users in the workplace for rehabilitation purposes is viewed in the rank ordering of objecttves. In addition, question 14 asks employers to identify the consequences of testing positive (e.g., are employees subject to disciplinary measures, counseling or immediate dismissal?). These options or combination of options highlight the degree of "punitiveness" assoclated with drug screening.

The remaining substantre questions deal with the costs of drug screening (question 15) and the effects of drug screening on labormanagement relations (questions 19 and 20). Question 15 asks city managers to estimate the costs of drug screening in their respective jurisdictions-particularly the costs of the test and the costs of administering the test for each employee tested. Questions 19 and 20 attempt to evaluate the degree of consensus between labor and management according to whether legal challenges have been mounted against drugscreening programs across the jurisdictions surveyed, and whether any of these challenges were successful and possibly contributed to alterations in the drug-screening policy.

This study represents a process evaluation rather than an impact evaluation. It is therefore preliminary in scope since impact evaluation can not occur without clearcut notions of what a program is supposed to accomplish. Where a process evaluation focuses on the way a program is implemented, the impact evaluation dwells more on the end results of programs. In this study, we examine the variations among drug screening programs and the differing objectives and means of implementation. Essentially, we are investigating what is done to whom and what activities are taking place as a result of drug screening. Those who will conduct impact evaluations in this area will examine whether a drug screening program actually reduced drug abuse in the workplace (1.e.. what happened to the target populations as a result of drug screening). ${ }^{28}$

\section{A Nationwide Survey of City Managers on Drug}

\section{Screening: The Findings}

From the 1,000 malled surveys, we recelved a response from 290 city managers - a 29 percent response rate. Out of 290 responses, 118 (40.7 percent) had implemented a drug-screening program whlle 172 (59.3 percent) had not. Of those who had not yet implemented drug testing, 62 (36 percent) were elther developing or considering a drug-screening or substance-abuse program. Many city managers (70) explained why they currently had no drug-screening program. (See Table 1 for their explanations.)

When asked to rank order the objecttves of their drug screening programs, city managers most frequently chose public safety as their primary objective. Second in Importance was maintaining employee safety. Their third greatest interest was ensuring the performance levels

of employees. Fourth and fifth in importance respectively were ensuring employee integrity and identifying drug users for purposes of rehabilitation. Other objectives that were suggested but not ranked in order of importance included malntalning the confidence of the public in the organization, protecting the city from llability sults, curtalling drug use in the surrounding community, weeding out potential problem employees, and complying with the law (see Table 2).

Table 1

City Managers' Dxplanation.

For Lack of Drug Bcreenling Policy

\section{Comments}

Low prionity itom

Perceived logal difficulties

No perceived need/no drug abuse

Union resistance

Too costly/ too time-consuming

Too political

Lack of statutory guidelines

City manager personally opposes a policy1

Total Number of Respondents

NOTE: Forty-ight of those who participated generally did not answer this question or lelt that if was not applicable to their drug screening programs.

Due process orientations of the drug screening programs are reflected In the responses to questions $6,7,8,9,10,11,12,13,16$ and 17. Also, questions 19 and 20 reflect employee views of mandatory drug testing by asking whether or not any legal challenges have been mounted against drug screening programs. The responses to questions 6 and 7 indicated whether city employees undergo mass screening, or whether certain occupation groups are targeted. These questions measure the basic intent of the program-why some groups are singled out while others are not.
2

70

\section{Number of Respondents}




\begin{tabular}{c} 
Table 2 \\
City Managers Rank Order \\
Objectives of Drug Bareening Pollcies \\
\hline
\end{tabular}

To maintain the periormance bvels of the employees
Ranks/Responses

Rank
$2: 9$
$2 \cdot 15$

$1: 9$
$2: 15$
$3: 45^{+}$

$4: 30$

$5: 10$ To ensure the honesty and integrity of employees in sensitive jobs
Ranks/Responses

$1: 8$

$2: 9$

$3: 26$

4:39*

$5: 26$

To maintain employee safely

Ranks/Responses

1:24

$2: 58^{*}$
$3: 20$

4:9

5: 0

To identify drug users for rehabilitation purposes

Ranks/Response:

$1: 1$
$2: 5$
$3: 8$
$4: 23$
$5: 59$

To proted the salety of the public

Ranks/Responses

$1: 70^{*}$

$2: 24$

3: 9

4:5

NOTE: " denotes the highest number of responses alboaled to the rank ordering of a particular
objoctive.
Table 3

Groups Targeted by Drug Screening Frograms

Which city employees (i.e., police or frefighters) are bargeted for drug screening?

\section{Responses}

Number of Reapondents

Police officers only

Firefighters only

All dity omployees

Pro-employment screening only

Reasonable suspicion only

Pre-employment and reasonable suspicion

Policeldispatcherslequipment operators

Policeffirefighters

Policolequipment operators

Policeffirefightersiransit divers'

department directors/equipment operators 2

Policefirefighters/ambulance operators/ bus

drivers/airport personnel/nurses/mechanics 1

Police/firefighters/school bus diversimpaired

employees

Police/firefighters/heavy equipment operators

public works employees

Public salety employees

Pro-employment/police/firefighters/reasonable

suspicion

mployees handling sensitive documents

$$
\text { public funds }
$$

No answerinot applicable

25

15

5

6

11

14

Total

118

Why wore these specific groups targeted?

Stateffederal regulations

Publidemployee safely

Nature of the job

th is logal

To protect the city from liability suits

screen out problem emplojees

To ensure employes integrity

To maintain grant funds

Groups that were targeted most frequently were police (25 respondents) and fireflghters (15 respondents). Another large segment of drugscreenlng programs tested all city employees (11 respondents) while 
others chose to engage in reasonable suspicion testing only (6 respondents) and pre-employment screening only (5 respondents). The most frequent reason gtven for targeting groups or for screening all employees was to maintain public and employee safety (47 respondents). See Table 3 for other explanations. Generally, the answers to this question are positively oriented toward due process, since most drug-screening programs employed were not mass-screening regardless of their relationship to public safety. Still, at least eleven programs screened all employees, and five screened them before hiring with no reasonable susplcion requirement

City managers were asked (in question 8) how regularly they conducted their drug screenings. The more regular the screenings, the more intrustve they are for city employees. The largest segment (20.3 percent) conducted drug screenings onty pror to employment and upon reasonable susplcion. Some screened for drug use only upon hirng employees (18.6 percent) while others screened only on a reasonable suspicion basis (18.6 percent). These responses accounted for 68 of the 88 respondents who chose to answer this question. Onty one respondent claimed to conduct dally screenings-the most undesirable use of a drug screening program when trying to balance employee needs for privacy against the governmental interests in public safety (see Table 4)

\section{Table 4}

The Regularity of Drug Screeninge

"How regulaty are drug screonings conducled? once a weok? once a month? other?

Responses

Number of Respondents

Pro-omploymentreasonable suspicion

Roasonable suspicion only

Prempleyment only

Annually

Biennially

On the job injuries/accidents

Biennialy until age 35/annually thereatie

Daily

Preemploymentannually

Premptoymentpromotion/annually

Presmployment/during police training

Proemployment for police and firefighters

probable cause br all

No answernol applicable

24

22

22

5

1

1

1

2

2

1

30

TOTAL
118
Approximately 78 percent claimed their drug screenings were mandatory for targeted groups; only 12 percent did not require participation. Mandatory testing without a direct government interest in ensuring employee integrity could be regarded as overly intrustve. Public safety was the most often cited reason for having a mandatory drug-screening program (5 respondents). Other reasons offered for mandatory participation by separate, individual respondants were: 1) adhering to federal mandate; 2) screening out problem employees; 3) following state policy and 4) job sensitivity. Reasons offered by separate, individual respondents for not making participation mandatory Included: 1) fear of legal difficulties; 2) the belief that such an approach would foster negattve labor-management relations; 3) the bellef that such programs are too costly, 4) the opinion that mandatory testing represents a privacy invasion; and 5) the feeling that there was no need for mandatory testing.

Another effort to gauge due process ortentations was made when city managers were asked whether their screenings were random. The majority (57.6 percent) rejected the use of random screenings fearing legal problems (10 respondents) and possible bad effects on labor-employer relations (1 respondent). One respondent claimed that random screenings did not occur "unless necessary." while another held that they only occured during an employee's probationary perlod. Approximately 17 percent claimed that screenings were random. A large segment (19.4 percent) chose not to respond to this question.

The majority of those surveyed (58.4 percent) claimed to abide by a reasonable suspicion standard. The remainder elther did not use this standard (13.5 percent); sometimes used this standard (3.4 percent): or chose not to answer the question (24.6 percent). Reasons offered for abiding by reasonable suspicion requirements included: 1) helping employees seek treatment (3 respondents); 2) protecting the employee and the organization (1 respondent); 3 ) maintaining public safety (3 respondents) and 4) avolding liability sults (2 respondents). Those who did not base screening on reasonable suspicion did not offer any relevant reasons for not using the standard. Most programs are due process ortented in the area of applying reasonable susplcton as a standard for testing employees.

To determine whether programs were orlented toward giving employees reasonable notice of testing, city managers were asked whether their drug screenings were announced or unannounced. The largest segment (35.6 percent) responded that their employees were given advance notice of drug screens. One respondent noted that announced screenings were based on unlon bargaining and agreement while two others believed announced screenings protected the ctvll rights of employees. Another 19.5 percent of the respondents used unannounced drug screenings while 10.1 percent only accasionally announced screenings (e.g.. in the instance where an employee is identified as a drug user on the grounds 
of reasonable suspicion). Thase who defended unannounced testing claimed that it was necessary to ensure the validity of drug tests. A large number of respondents ( 34.7 percent) chose not to answer this question.

City managers were also asked whether their jurisdictions conducted follow-up screenings when an employee tested posittve in an initial screening. This is a due process question almed at determining whether employees might be subject to firing or disciplinary measures without additionally testing for veracity. Most respondents (65.2 percent) used follow-up testing; only 5.9 percent did not. However, 28.8 percent of the sample chose not to respond. Of those who used follow-up tests, they used them to confirm positive tests (25 respondents) and to monitor employee rehabilitation (14 respondents). For those respondents who did not use follow-up testing, the only reason given was positive testees simply were not hired.

When asked what were the consequences of testing positively in the drug screening, the city managers were given a list of three possible consequences and were asked to circle the ones that applied to their jurisdictions. The following alternatives were presented to them:

A. Those who test positively are subject to disciplinary measures.

B. Those who test positively are encouraged to attend counseling

and/or to participate in an employee assistance program.

C. Those who test positively are immediately discharged.

D. Other (please specify)

The respondents could circle more than one response. The consequence most frequently chosen was (B)-circled by 79 respondents. Equally popular was (A) which was selected by 73 respondents. Discharging positive testees immediately was the least popular approach: with only 23 respondents choosing this alternattve. This question was used to indicate the punitive versus rehabilitative approaches that may be taken when employing drug screenings. Most programs appear to be rehabilitattvely oriented. Nineteen respondents specified that they simply did not hire applicants who tested positively in a drug screening while two others claimed that the response to a posittve test was not automatic and had to be handled according to individual circumstances.

The costs of testing was another concern-particularly if drug screening becomes more widespread. Costs were varlable but most respondents (41.5 percent) claimed that costs of testing ranged between $\$ 10$ to $\$ 50$ per test. Another 18.6 percent acknowledged greater costs-estimating a range between $\$ 51$ to $\$ 250$ per test. Some respondents provided annual cost estimates ranging from $\$ 600$ a year (2 respondents) to $\$ 5,000$ a year (1 respondent). Many respondents (39.9 percent) did not know the costs of testing or had not actually tested anyone yet. Most city governments (51.6 percent) rely on urine samples for testing-the most intrustve and problematic testing procedure; 22.8 percent use both urine and blood samples for testing, depending on the individual circumstances. Another samples for testing, depending on the individual clrcumstances. Another 6.7 percent rely only on blood samples; 1.7 percent used blood, urine and
breathalizer tests. This question was not answered by 18.6 percent of the sample.

Drug-screening policles were well-publicized and ctrculated among Drug-screening policles were well-publicized and circulated among
employees: 64.4 percent of respondents noted the importance of this while approximately 17 percent clalmed the pollcies were not wellpublicized. The remainder chose not to answer this question.

Almost no one questioned the accuracy of the tests. Since these Almost no one questioned the accuracy strategy, most felt compelled to staunchly support their programs by asserting a strong belief in accuracy. Evidence discussed earlier indicates some of the accuracy accuracy. Eroblems of uninalysis in particular. Either respondents were unaware of problems of urinalysis in particular. Elther red accuracy problems: 79.6 percent claimed that they belleved in the accuracy of the tests they percent claimed. When asked why they belleved in the accuracy of their tests. 18 respondents claimed that follow-up tests ensure accuracy while 18 respondents claimed thal follow-up independant laboratories with another 18 respondents believed that independant laboratories with reputable records ensured accuracy. Two cited that there was a welldocumented chain of custody when transporting specimens and believed that this protected test accuracy. No one said that they did not belleve in their accuracy but one respondent tentatively asserted that the tests were not totally accurate. Concern that someone might be wrongfully accused by inaccurate tests was low since no one ralsed any questions at all about the accuracy of these tests.

Nationwide, from this sample there were seven legal challenges mounted against drug-screening programs in the public sector. This is mounted ar that drug screenings are causing tension between labor and man indicator that drug screenings are causing The reasons given for the challenges included llegal search and selzure, privacy violations, unfalr labor practices, and adverse reactions to mandatory and random testing as the reasons for discontent. For the other 92 respondents, no challenges had been mounted in their jurtsdictions. One challenge was reported as successful wherein the respondent stated that the court prohibited random testing, requiring a respondent stated that the court instead. The remaining respondents replied that there were no successful legal challenges.

replled that there were no successul legal challenges. Most programs appear to be mass screening, 2) by announcing tests groups to test rather than usco ing, 3) by publictzing the drug screening rather than using random scees. and 4) by relying on follow-up tests to policy to affected employees, and 4) by relying on concern for the confirm or disconfirm positive tests. However, more concern for the accuracy of these tests should be shown. Most respondents ranked their drug- screening programs. On the other hand, most of them did 

for drug use. The truly punitive programs were those that would not hire
applicants as a result of an initial drug screening.

\section{opulation Size Findings}

All the results were sorted according to city population size. There were seven sizes ranging from smallest to largest: 1) 10,000-24,999 residents; 2) 25,000-49,999 residents; 3) 50,000-99,999 residents; 4) 100,000 249,999 residents; 5) 250,000-449,999 residents; 6) 500,000-1,000,000 residents; and 7) over $1,000,000$ residents. The rank ordering of objecttves corresponds across city size to the results obtained in the national and reglonal breaksowns. One expected but interesting vartation is that the larger the city, the more likely it is to have a drug
screening program.

Table 5

\section{Drug Sereening Programs by City size}

10,000 - 24,999: With Policy-34; Whout Policy-97 - 131

25,000 - 49,999: With Policy-39; Without Policy-49=88

50,000-99,999: With Policy-24; Without Policy-16 = 40

100,000 - 249,999: With Policy-13; Without Policy-7 = 13

250,000 - 449,999: With Policy-5; Without Policy-2 = 7

500,000- Over 1,000,000: Win Policy-3: Wathout Policy $=1$

In citles with 10,000-24,999 residents, 25.8 percent of respondents had implemented a drug-screening program. In cities with 25,000 49,999 residents, 44 percent of respondents had drug screening programs. Sixty percent of citles with $50,000-99,999$ populations had protesting programs; 65 percent of citles stzed 100,000-249,999 possessed drug screening programs. In citles with 250,000-449,999 residents, 71.4 percent of respondents had implemented drug-screening programs. Three-fourths of cities with populations over 500,000 had drug-screening programs. This was the most significant difference found according to population size. For the breakouts of those clties with policles and those cities without policles based on size, see Table 5 .

\section{Conclusions}

The findings indicate that city managers rank order the objectives of their drug screening programs in the following order of importance: 1) public safety; 2) employee safety; 3) ensuring employee performance levels; 4) ensuring employee integrity; and 5) rehabilitation of employees who use drugs. Groups targeted most frequently for drugscreenings were police, firefighters, and city employees. The great majority of drug screenings were mandatory, not voluntary. Most conducted drug screenIngs prior to employment, upon hiring or on a reasonable suspicion basis. Over half of all city managers surveyed rejected random drug screenings with a large segment responding that employees were gtven advanced warning of drug screenings. A majority of city managers also indicated that follow-up screenings for employees testing posittvely were used.

Most of the drug screening programs appear to take due process lssues serlously. They generally are not punittve in nature but at the same time rehabilitation was not ranked as a top priority. Many city managers are cautious about Instituting a punitive component within their drug screening programs in part due to legal controversies that might be generated and also due to fears that labor-management relations would be damaged. Future court rulings will play a decistve role in determining whether due process/prtvacy issues will be taken serlously in the future, and the message from the White House combined with court rullings may determine the punittveness of future programs.

These findings suggest that more attention should be pald to the accuracy of the drug-screening tests employed by city managers. A majority of managers percelve high levels of confidence in their testing procedures. At the same time evidence shows that they are relying on highty inaccurate urine tests. Indeed, only the most advanced and expensive urine screenings approxdmate the accuracy levels necessary before accusing employees of drug abuse and damaging their reputations.

The future direction of drug-screening programs should be examined carefully by local public managers. Given the many problems associated with drug screening, alternatives to urine testing, in particular, should be considered. Many prtvate employers have opted not to use urine screenings because they believe such tests: 1) represent serlous invaslons of privacy, 2) can not show on-the-job impairment, and 3) will impact negattvely on employee morale. ${ }^{20}$

Besides these apprehensions, false positive results may lead to the firing of innocent employees or, in the case of pre-employment tests, to not hiring potentially innocent and competent employees. Drug-screening programs may deter employees from taking prescription drugs on the job which would enhance their efficiency due to fears of informing employers about illnesses that may be percetved as debilitating. Another reason for considering alternatives to drug-screening programs is that they involve public managers in law enforcement activities which take time and resources away from conducting very important public business.

Some suggested alternattves to drug-screening programs include: 1) drug awareness and education programs; 2) constructive confrontation by a supervisor when employee performance declines and subsequent referral to an appropriate employee assistance program; and 3) peer 
referral to employee assistance programs in workplace settings where supervisors do not have close contact with their employees. These approaches may solve the problem of employee impairment due to drug abuse as effecttvely, or perhaps even more effectively, than drug-screening programs. Drug abuse in the workplace is a real problem but we need to find solutions that are consistent with our cultural and legal ideals (i.e., the right to prtvacy and the right to be free from unreasonable searches and seizures).

\section{Notes}

'Congressional Digest, "Reagan Administration Drug Testing Program," May, 1987, pp. 131-132

"CIS Annual Legislative Histories, "Anti-Drug Abuse Act of 1988," P.L. 100-690 (18 November), 100th Congress, 2nd Session, 1988, p. 814; U.S. Code \& Congressional Administrative News, "Subtitle D-Drug-Free Workplace Act of 1988," P.L. 100-690, Subtitle D, Sections 5151-5160, January 1989, 102 Stat., pp. 4304-4307.

${ }^{3}$ Congressional Almanac, "Walker's Drug-Free Workplace Plan," 1988, p. 94.

4American Medical Association Research Study, Drug Abuse: The Workplace issues, (New York: AMA Membership Publications Div., 1987).

5John Tanner, Jern Kinard, Sam Cappel, and Peter Wright, "Substance Abuse and Mandatory Drug Testing in Health Care institutions," Health Care Management Review, 13:4 (1988), p. 33.

"USA Today, "Drugs in the Workplace," 11 October 1989, p. 1 B.

Thomas R. Horton, "Drugs in the Workplace," Public Management, 69:9, September 1987, p. 2.

'Theodore H. Rosen, "Identification of Substance Abusers in the Workplace," Public Personnel Management, Fall 1987, p. 198.

"Peter Reuter, "Testing and Deterrence," Journal of Policy Analysis and Management, Spring 1988, p. 554.

10Tanner, et al., p. 33.

"Dale A. Masi, Designing Employee Assistance Programs (Now York: American Management Assoc., 1984), pp. 102-104.
12Reuter, pp. 554-556; William G. Tallman, "Guidelines for Drafting a Drug (2)

${ }^{13 T e r r e n c e ~ R . ~ C o w a n, ~ " D r u g s ~ a n d ~ t h e ~ W o r k p l a c e: ~ T o ~ D r u g ~ T e s t ~ o r ~ N o t ~ t o ~ T e s t ? " ~}$ Public Personnel Management, Winter 1987, p. 317. 14Anne Marie O'Keefe, "The Case Against Drug Testing," Psychology Today, 21:6, June 1987. and Public Employment: Toward a Rational Applicallonol Winter 1988, p. 263.

15O'Ke日ie, p. 35.

作 ${ }^{16}$ Abbie Hoffman and John Silvers, Steel This Unine Test: Fighing Drug Trebach, in America (New York: Penguin Books, 1987), pp. 198-199; Arnorica Safe Again The Great Drug War: Radical Proposals That Could Make $231-237$.

(Now York: MacMillan Publishing

${ }^{17}$ Hoffman and Silvers, p. 200.

180'Keefe, p. 35; Feiman and Petrini, pp. 265-266.

19Rosen, p. 202; Felman and Petrini, p. 266.

20Felman and Petrini, p. 262; Hoffman and Sitvers, p. 204; Rosen, p. 201.

${ }^{21}$ Felman and Petrini, pp. 206-207.

22Folman and Petrini, p. 274.

3 Tumer v. Fraternal Order of Police, 500 A.2d 1005 (D.C., 1985); McDonnel v. Hunter, 612 F. Supp. 1122 (S.D. lowa, 1985).

${ }^{24}$ Patchogue-Medford Congress of Teachers v. Board of Education, 510 N.E. $2 d$ 325 (N.Y., 1987).

25Martin F. Payson and Philip B. Rosen, "Substance Abuse: A Crisis in the Workplace," Trial, July 1987, pp. 25-34.

${ }^{26}$ American Federation of Govemment Employees v. Dole, 670 F. Supp. 445 (D.C., 1987).

2. Cxocutives' Association, 105 ${ }^{27}$ Consolidated Rail Corporation v. Rallway Labor'Unionv. Von Raab, 103 L.Ed. L.Ed.2d 250 (1989); National Treasury Employees' Unionv. Von Raab, 103 I.Ed. 2d 2d 685 (1989); Skinner v. Railway Labor Executives Associalion, 103 I.Ed. $2 d$ 639 (1989). 
${ }^{28}$ Karen Sue Trisko and V.C. League, Developing Successful Programs (Oakland, Calif.: Awareness House, 1978); Richard D. Bingham and Claire L. Felbinger, Evaluation in Practice: A Methodological Approach (New York: Longman, 1989), pp. 4-6.

2oKevin B. Zeese, Drug Testing Legal Manual: Guidelines and Attematives (New York: Clark Boardman Co., 1989), p. 9-2.

\section{Other Sources}

Public Management. "Commentary: Local Government Policies," 69:9, September 1987, pp. 11-13.

Spolar, Chris. "Drugs in the Workplace: What Workers Do Off Their Jobs Is Becoming an Issue," Washington Post National Weekly, January 23-29, 1989, pp. 6-7.

Ruth Ann Stricktand is a member of the Department of Polltical Sclence and Criminal Justice at Appalachlan State University, Boone, North Cardina; Marcla Lynn Whicker is a professor of Public Administration at Vinginla Commonwealth

Unwersity, Richmond, Virginia.

\section{Make a Note of the National Civic League's New Address!}

Effective January 7, 1991, our mailing address changes from 1601 Grant Street, Suite 250. Denver, CO 80203 to:

1445 Market Street, Suite 300

Denver, CO 80202-1728

Tel: (303) 571-4343/FAX: 571-4404 